\title{
External Debt and FDI in Kosovo, Stimulating Growth
}

\author{
PhD. Nakije Miftar Kida \\ College AAB, Pristina, Albania
}

\begin{abstract}
My work is based on statistical analysis of annual data for GDP, FDI, Infrastructure and External Debt for Kosovo. They show that there was a delay in GDP growth by inappropriate trajectory configuration of positive and negative increase or decrease of economic components, some of which are included in the analysis, FDI, Infrastructure and External Debt. FDI has a positive reflection on GDP growth but it presents no statistical significance. Even the CBK statistics for FDI inflows in Kosovo show the lowest level especially after 2007, with minor improvements these last two years. While, considered as an important factor in the GDP growth, Infrastructure is represented by cellular telephone lines which cover $98 \%$ of the territory of Kosovo. Our empirical results suggest that external debt has had a negative impact on economic growth even though the coefficient is low, the evidence shows that the external debt is increasing and this has important implications for the economy and public policies in Kosovo.
\end{abstract}

Keywords: FDI, GDP, external debt, Infrastructure, Republic of Kosovo.

\section{Introduction}

Kosovo is known as a country with low income, but it has been able to manage the public finances. The position of net international investment since 2007 - 2016 reaches a value of 3,036.1 million euro (2016 brought a reduced inflow of 215.9 million euro). A very low employment rate in Kosovo is a concerning indicator which in 2012 was 25 percent, while the official unemployment rate was 30.9 percent, that can be even greater. Since during the period from 2000 to 2006 Kosovo had no external debt, it had a positive effect on taxes in Kosovo, because it did not promote the growth of tax rates, but on the contrary their reduction. This positively affects the perception of investors that there will be no tax increase in the future to cover the external debt. External debt (http://bqk-kos.org/?id=55) size reflects negatively on FDI flows. Although exports were lower in the period from 2000 to 2006, they were not directed to the coverage of external debt, since it did not exist. Financial position (2007 - 2013) expressed below shows that in 2007 it was positive with 27.1 million euro of inflows from exports in the country in relation with the external debt. While the financial position after 2006, where the first debts began, is not satisfactory with the small contribution of exports. Kosovo has the lowest external debt in the region of 1.5 billion euro in 2013 (MF 2015). External assets in debt instruments, that are 3.245 .2 million euro, gross external debt is 2,012.2 billion euro in 2016, net external debt remains -1.230.9 million euro. As GDP \% external debt in 2011 from 5.51\% of GDP, in 2014 from $10.63 \%$ of GDP, while the debt continues to grow as $\%$ of GDP. The bloom of the telecommunications sector in the country through the major telecommunications operators: Post and Telecommunications of Kosovo (PTK), IPKO and Kujtesa. By the end of 2010, Kosovo had a penetration rate of 4.26 percent in fixed-line services, 72 percent in mobile communications, and 6.31 percent in internet services while in 2016 it covers $98 \%$ of mobile services. The reported penetration rates, especially for Internet services, show that there is still place for further investment in this sector. 


\section{FDI Theoretical Basing}

The purpose of this paper is to evaluate the effects of FDI on economic growth, as well as to identify the factors of external debt and infrastructure as factors that can stimulate the GDP growth. Since FDI and savings in developing countries at national-level are quite low (Anghion and Howitt (1992), this encourages the developing countries to seek for capital through expanding their markets. GDP growth is usually parameter to measure the economic growth of a country, even though it is not the only parameter. GDP includes the overall production within the country for the given period. Foreign Direct Investment is included in GDP and a lot has been done to discover the relationship between FDI and the growth. In the majority of studies, the "OLI" paradigm or Dunning's eclectic theory is used to prove the hypotheses related to this issue. Growth of per capita income within a country through increasing the level of current production is one of the main objectives of the economy. The close relationship between GDP, level of the current production, income per capita and FDI, has led the various researchers to find solutions to the key security concerns of the GDP growth. In other words, an increase in GDP, the market value of all products and services produced within a country each year in proportion to the population, is defined as the economic growth. Each country aims the economic growth, and if this is not available through the internal sources, then external capital in cash, capital markets and foreign investment, by creating a new branch, the purchase of the existing one, or through the reunification, is one of the means of closing the shortfall in capital (Seyidoğlu, 1999: 664., Kurtaran, 2005: 367, YIImazer, 2010: 242). The relationship among FDI and GDP, domestic savings, stock of capital, use of advanced technology and its use (human capital) and amounts of investments are widely accepted as the main determinants of the economic growth.

The purpose of the Study - The purpose of this study is providing answer to the research question related to the impact of FDI and external debt on economic growth in Kosovo. This paper has the objective:

To analyze the impact of FDI, infrastructure and external debt on GDP, through multiple regression and Pearson correlation.

Reference sources - The paper is based on annual data published by the Central Bank of Kosovo (CBK) and the International Monetary Fund (IMF), considered as the secondary sources, the Kosovo Statistics Agency (KSA), PTT, IPKO, Kujtesa, etc.

Research objectives - Study of the FDI flow trends; overview on the stability of macroeconomic indicators in Kosovo, GDP, FDI and External Debt.

Research question: How have FDI, infrastructure and external debt affected the GDP growth in Kosovo?

Hypothesis: Impact of FDI and infrastructure and the stimulating negative effect of the external debt on the GDP growth in Kosovo are low.

The importance of the study - However, the importance of this study is its time horizon increase compared with the previous ones in terms of FDI impact, external debt and infrastructure on real GDP growth in Kosovo.

\section{The research methodology}

Methodology is very important background that helps to explain the procedures which lead to the results of the study for the reader to understand them. The model - research uses the OLS technique, a good measure (Kontsoyannis 1997) of objectives in such analyzes with more than one independent variable as in our case. Specification of the equation is done as follows:

$$
\begin{aligned}
& \text { GDPit }=-\beta_{0}+\beta_{1} \text { FDlit }+\mathrm{u} \ldots \ldots \ldots \ldots \ldots\left(\mathrm{eq}_{1}\right) \\
& \text { GDPit }=-\beta_{0}+\beta_{1} \text { BJlit }++\mathrm{u} \ldots \ldots \ldots \ldots . .\left(\mathrm{eq}_{2}\right)
\end{aligned}
$$


GDPit $=-\beta_{0}+\beta_{1} I N F l i t+u$

$\mathrm{GDP}=$ Per capita growth rate; FDI = Foreign Direct Investment; $\mathrm{BJ}=$ External debt; INF = infrastructure; $\mathrm{u}=$ the error term. $\beta 0, \beta_{1}$, are the parameters to be estimated.

The economic criteria help us whether coefficients of the equation will have positive values or not, while the statistical criterion checks the $T$ value and statistical significance of the $F$ test. While $\mathrm{R}^{2}$, will be used to determine the explanatory variables. Whereas econometric criteria are assessed through tests to assess whether at the Linear Regression method are violated the assumptions on autocorrelation (Durbin-Watson), multicollinearity between variables and heteroscedasticity. Selection of the OLS model is suitable for testing our specific hypothesis that aims measurement of economic relations' nature (Gurajati, 2004). Macroeconomic indicators of an economy are considered as key factors for FDI inflows to a country (Kosmidou. K, 2008). Use of GDP (Lopes et al. (2002); Ivanov. S. and Webster. C. (2007), Malul. $\mathrm{M}$, et al (2008), is of great interest in our case. Focus group (at the secondary data) selected the variables, FDI, GDP, Infrastructure and external debt. - The program SPSS, 19, has served for statistical processing of paper records. To achieve the objectives of the study, the analysis of simple regression and Pearson correlation is conducted, using the important econometric techniques. So the simple regression analysis was used to identify major variables (determinants) that have impact on GDP. The coefficient of determination $R^{2}$, Durbin - Watson statistics [D-W], standard error of the coefficients, t-statistics, F-ratio, and other important econometric tests have been conducted to evaluate the relative importance and judgment reliability of the model parameters.

\section{Study results}

Since there are restrictions on the number of observations, this is completed through the used model, which has great significance in comparison with other models. The first tests we will perform to prove the accuracy of the model are:

o Test $r^{2}$ at least $R^{2}>60 \%$, but $R^{2} \neq r$ of correlation; for, $k \geq 2$,

o Fisher (ANOVA) is simultaneous test on the variance $\beta$, paving two hypotheses:

$H_{0}: \beta=0$, so the relation does not exist,

$\mathrm{Ha:} \beta \neq 0$, the relation exists

o Factic Fischer $\mathrm{Ff}<\mathrm{Fc}$ Critical Fischer, end as the Hypothesis 0 wins, ie $\beta=0$

$\circ$ T-sudent, on variance $\beta$ (is performed for each coefficient one by one).

$\mathrm{H}_{0}: \beta=0$, so the relation does not exist,

Ha: $\beta \neq 0$, the relation exists

To variables, we have data about, since 2007-2016, is performed a simple regression analysis for each dependent variable. The dependent variable, - the real GDP, while the independent variables are FDI, external debt and infrastructure.

Table 1: Descriptive Statistics from the time series (author's work, data from CBK-time series 2007-1016).

\begin{tabular}{|c|c|c|c|c|}
\hline & & $\begin{array}{l}\text { GDP in million } \\
\text { Euro- } €\end{array}$ & $\begin{array}{l}\text { External Debt expressed in } \\
\text { million Euro, } \\
\text { in the period 2007-2016 }\end{array}$ & $\begin{array}{l}\text { FDI - 2007-2016, which are } \\
\text { expressed in milion Euro- } € \text {. }\end{array}$ \\
\hline $\mathrm{N}$ & Valid & 14 & 10 & 10 \\
\hline & & 3.4 & 7.4 & 2.46 \\
\hline & & 1.19 & 1.11 & 1.42 \\
\hline
\end{tabular}

Source: CBK, 2016, time series, author's work

The second best variable from distribution, after the annual GDP, is the logarithm of FDI having an average of 1.42 units with a distribution from an average of 2.46 units, indicating that even in this case the distribution is concentrated during our period of analysis. At the Eternal Debt, the distribution of values is 1.11 units from average of 7.4 units. At the Infrastructure, the distribution of values is 1.13 units from average of 2.3 units. This indicates that these variables have concentrated distribution throughout the analysis period (2007-2016). 


\section{Evaluation of FDI impact on real GDP, with no time delay}

The $R$ value represents simple correlation that is .0241 , which shows a low degree of correlation. $R^{2}$ value ("R Square") is the Fraction of total variation that is explained by regression; $R^{2}$ is a measure of the model explanatory power which shows how far the variance of the dependent variable can be explained, in our case - GDP - with the independent variable, -FDI 2004-2013. In this case 5.8\% can be explained, which is very small. The next table is ANOVA, which reports how well the regression equation fits the data (ie, predicts the dependent variable). This table shows that the regression model does not predict the dependent variable in a statistically significant way. Why is that so? Look at the "regression" line and see the value of "Sig." which shows the statistical significance of the regression model. In our case, $p=.503$ is more than 0.05 , and shows that the regression model does not statistically predict the result.

Table 2: Model Summary

\begin{tabular}{|c|c|c|c|c|c|c|c|c|c|c|}
\hline \multirow[b]{2}{*}{ Model } & \multirow[b]{2}{*}{$\mathrm{R}$} & \multirow[b]{2}{*}{ R Square } & \multirow[b]{2}{*}{$\begin{array}{l}\text { Adjusted R } \\
\text { Square }\end{array}$} & \multirow[b]{2}{*}{$\begin{array}{l}\text { Std. Error of } \\
\text { the Estimate }\end{array}$} & \multicolumn{5}{|c|}{ Change Statistics } & \multirow[b]{2}{*}{$\begin{array}{l}\text { Durbin- } \\
\text { Watson }\end{array}$} \\
\hline & & & & & $\begin{array}{l}\text { R Square } \\
\text { Change }\end{array}$ & F Change & df1 & df2 & \begin{tabular}{|l} 
Sig. F \\
Change
\end{tabular} & \\
\hline 1 & $.241^{a}$ & .058 & .060 & $8.593 \mathrm{E} 8$ & .058 & .493 & 1 & 8 & .503 & 176 \\
\hline
\end{tabular}

a. Predictors: (Constant), FDI-Inflows for the years 2004-2013, that are expressed in Million Euro- $€$.

b. Dependent Variable: GDP

ANOVA

\begin{tabular}{|l|l|l|l|l|l|}
\hline Model & Sum of Squares & Df & Mean Square & F & Sig. \\
\hline Regression & $3.639 \mathrm{E} 17$ & 1 & $3.639 \mathrm{E} 17$ & .493 & $.503^{\mathrm{a}}$ \\
Residual & $5.908 \mathrm{E} 18$ & 8 & $7.385 \mathrm{E} 17$ & & \\
Total & $6.272 \mathrm{E} 18$ & 9 & & & \\
\hline
\end{tabular}

a. Predictors: (Constant), FDI-Inflows for the years 2004-2013, that are expressed in Million Euro- $€$.

b. Dependent Variable: GDP

Table "Coefficients" provides us with the necessary information to predict GDP from FDI for the years 2004-2013, as well as to determine whether FDI statistically contributes significantly to the model (by looking at the "Sig."). Moreover, we can use the values in the "B" column under the "Unstandardized Coefficients" column, as shown below, to present the regression equation:

Equation 1: $\mathrm{GDP}=3.619+1.410$

Corficienta

\begin{tabular}{|c|c|c|c|c|c|c|c|c|c|}
\hline \multirow[b]{2}{*}{ Mode } & & \multicolumn{2}{|c|}{$\begin{array}{l}\text { Unstandardized } \\
\text { Coefficients }\end{array}$} & \multirow{2}{*}{$\begin{array}{l}\text { Standardized } \\
\text { Coefficients } \\
\text { Beta }\end{array}$} & \multirow[b]{2}{*}{$T$} & \multirow[b]{2}{*}{ Sig. } & \multicolumn{3}{|l|}{ Correlations } \\
\hline & & $B$ & Std. Error & & & & Zero-order & Partial & Part \\
\hline 1 & (Constant) & 3.619E9 & 5.636E8 & & 6.421 & .000 & & & \\
\hline & $\begin{array}{l}\text { FDI-Inflows for the } \\
\text { years } 2004-2013 \text {, which } \\
\text { are expressed in Million } \\
\text { Euro- } € \text {. }\end{array}$ & 1.410 & 2.008 & .241 & .702 & .503 & .241 & .241 & .241 \\
\hline
\end{tabular}

a. Dependent variable: GDP

\section{Evaluation of the Infrastructure impact on real GDP growth}

The $R$ value represents simple correlation that is .979 , which shows a high degree of correlation. $R^{2}$ value ("R Square") is the Fraction of total variation that is explained through regression; $R^{2}$ is a measure of the model explanatory power which 
shows how far the variance of the dependent variable can be explained, in our case - GDP - with the independent variable, Infrastructure 2007-2016. In this case $95.9 \%$ can be explained, which is very big.

The next table is ANOVA, which reports how well the regression equation fits the data (ie, predicts the dependent variable) .This table shows that the regression model predicts the dependent variable in a statistically significant way. In our case, $p$ $=.000$ is less than 0.05 , and shows that the regression model statistically predicts the result.

Model Sumaryb

\begin{tabular}{|l|l|l|l|l|l|}
\hline Model & R & R Square & Adjusted R Square & $\begin{array}{l}\text { Std. Error of the } \\
\text { Estimate }\end{array}$ & Durbin-Watson \\
\hline 1 & $.979 \mathrm{a}$ & .959 & .950 & $1.394 \mathrm{E} 8$ & 2.708 \\
\hline
\end{tabular}

a. Predictors: (Constant), Infrastructure as \% of population

b. Dependent Variable: GDP - according to the actual costs after the correction in billion Euro

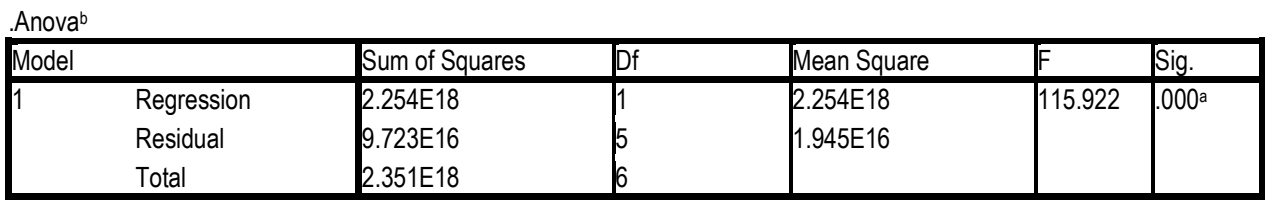

a. Predictors: (Constant), Infrastructure as \% of population.

b. Dependent Variable: GDP - to the actual costs after the correction in billion Euro

Coefficienta

\begin{tabular}{|c|c|c|c|c|c|c|c|c|c|c|c|c|}
\hline \multirow[b]{2}{*}{ Model } & \multicolumn{2}{|c|}{$\begin{array}{l}\text { Unstandardized } \\
\text { Coefficients }\end{array}$} & \multirow{2}{*}{\begin{tabular}{|l} 
Standardi \\
zed \\
Coefficien \\
ts
\end{tabular}} & \multirow[b]{2}{*}{$\mathrm{T}$} & \multirow[b]{2}{*}{ Sig. } & \multicolumn{2}{|c|}{$\begin{array}{l}95.0 \% \text { Confidence } \\
\text { Interval for B }\end{array}$} & \multicolumn{3}{|c|}{ Correlations } & \multicolumn{2}{|c|}{$\begin{array}{l}\text { Collinearity } \\
\text { Statistics }\end{array}$} \\
\hline & B & Std. Error & & & & $\begin{array}{l}\text { Lower } \\
\text { Bound }\end{array}$ & $\begin{array}{l}\text { Upper } \\
\text { Bound }\end{array}$ & $\begin{array}{l}\text { Zero- } \\
\text { order }\end{array}$ & Partial & Part & $\begin{array}{l}\text { Tolera } \\
\text { nce }\end{array}$ & VIF \\
\hline $1 \quad$ (Constant) & 1.812E9 & 2.437E8 & & 7.435 & .001 & 1.186E9 & 2.439E9 & & & & & \\
\hline $\begin{array}{l}\text { Infrastructure } \\
\text { as } \% \text { of } \\
\text { population }\end{array}$ & 31.5912 & 28.259 & .979 & 10.767 & .000 & 23.245 & 38.579 & .979 & .979 & .979 & 1.000 & 1.000 \\
\hline
\end{tabular}

a. Dependent Variable: GDP - to the actual costs after the correction in billion Euro

Table "Coefficients" provides us with the necessary information to predict GDP from Infrastructure for the years 2006-2016, as well as to determine whether Infrastructure statistically contributes significantly to the model (by looking at the "Sig."). Moreover, we can use the values in the "B" column under the "Unstandardized Coefficients" column, as shown below, to present the regression equation:

Equation 2: GDP $=1.812+31.5$

\section{Evaluation of the external debt impact on real GDP growth}

Model Sumary

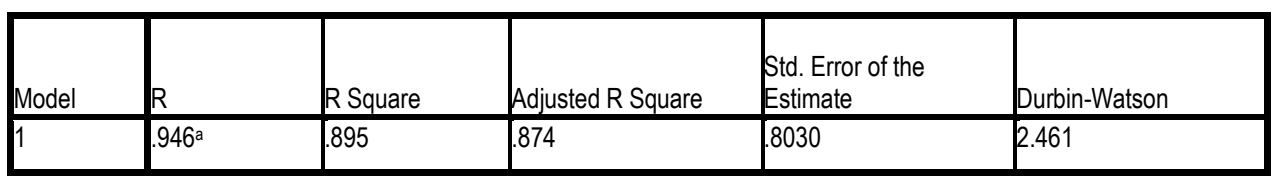


a. Predictors: (Constant), External Debt expressed in Million Euro, in the period 2007-2013 b. Dependent Variable:real GDP

Anovab

\begin{tabular}{|ll|l|l|l|l|l|}
\hline Model & & Sum of Squares & Df & Mean Square & F & Sig. \\
\hline 1 & Regression & 27.376 & 1 & 27.376 & 42.456 & $.001^{\text {a }}$ \\
& $\begin{array}{l}\text { Residual } \\
\text { Total }\end{array}$ & 3.224 & 5 & 645 & & \\
& 30.600 & 6 & & & \\
\hline
\end{tabular}

a. Predictors: (Constant), External Debt expressed in Million Euro, in the period 2007-2013

b. Dependent Variable: Economic growth / Real growth rate after correction / To actual costs

The $R$ value represents simple correlation and it is . 946 which shows a high degree of correlation. $R^{2}$ value (" $R$ Square") is the Fraction of total variation explained by regression; $R^{2}$ is a measure of the model explanatory power which shows how far the variance of the dependent variable can be explained, in our case - GDP - with the independent variable, External debt 2007-2016. In this case $89.5 \%$ can be explained, which is very big. The next table is ANOVA, which reports how well the regression equation fits the data (ie, predicts the dependent variable). This table shows that the regression model does not predict the dependent variable in a statistically significant way. Look at the "regression" line and see the value of "Sig." which shows the statistical significance of the regression model. In our case, $p=.0 .01$ is less than 0.05 , and shows that the regression model statistically predicts the result. Table "Coefficients" provides us with the necessary information to predict GDP from FDI for the years 2007-2016, as well as to determine whether External debt statistically contributes significantly to the model (by looking at the "Sig."). Moreover, we can use the values in the "B" column under the "Unstandardized Coefficients" column, as shown below, to present the regression equation or:

Equation 3: GDP $=10.803-5.193$

Coefficienta

\begin{tabular}{|c|c|c|c|c|c|c|c|c|c|c|c|c|}
\hline \multirow[b]{2}{*}{ Model } & \multicolumn{2}{|c|}{$\begin{array}{l}\text { Unstandardized } \\
\text { Coefficients }\end{array}$} & \multirow{2}{*}{$\begin{array}{l}\text { Standardi } \\
\text { zed } \\
\text { Coefficien } \\
\text { ts } \\
\text { Beta }\end{array}$} & & \multirow[b]{2}{*}{ Sig. } & \multicolumn{2}{|c|}{$\begin{array}{l}95.0 \% \\
\text { Confidence } \\
\text { Interval for B }\end{array}$} & \multicolumn{3}{|c|}{ Correlations } & \multicolumn{2}{|c|}{$\begin{array}{l}\text { Collinearity } \\
\text { Statistics }\end{array}$} \\
\hline & $B$ & $\begin{array}{l}\text { Std. } \\
\text { Error }\end{array}$ & & t & & $\begin{array}{l}\text { Lower } \\
\text { Bound }\end{array}$ & $\begin{array}{l}\text { Upper } \\
\text { Bound }\end{array}$ & $\begin{array}{l}\text { Zero- } \\
\text { order }\end{array}$ & Partial & Part & $\begin{array}{l}\text { Toleran } \\
\text { ce }\end{array}$ & VIF \\
\hline $1 \quad$ (Constant) & 10.803 & .999 & & 10.812 & .000 & 8.234 & 13.371 & & & & & \\
\hline $\begin{array}{l}\text { External Debt } \\
\text { expressed in } \\
\text { Million Euro, in } \\
\text { the period 2007- } \\
2013\end{array}$ & $-5.193 E-9$ & .000 & -.946 & -6.516 & .001 & .000 & .000 & -.946 & .946 & -.946 & 1.000 & 1.000 \\
\hline
\end{tabular}

a. Dependent Variable: Economic growth / Real Growth rate after correction / To actual costs;

b. Constant variable: External debt in million euro

\section{Conclusion}

This paper examines the impact of FDI, External Debt and Infrastructure on GDP growth in Kosovo during the period 2007 - 2016. The general conclusion is that the infrastructure affects positively and significantly to GDP growth and FDI attracting. From all the above analysis on the effect of various determinants on GDP growth, we can conclude that FDI inflows in Kosovo, measured out "separately" without time delay, have insignificant effect but not negative. When the model proves external debt as determinant of GDP growth, there is seen the negative effect with a coefficient of -5.193 with the value of significance $p=0.01<0.05$. This is proved by the simple correlation $R(0.946)$ and determination coefficient $R^{2}(0.845)$ that are much higher than $84.5 \%$. F-statistic (61.685) is also high compared with t-student (F-critical 2.678). While the table also 
reports that the model is significant ( $p$-value $e=0.001<0.05$ ). Meanwhile the opposite occurs, the impact of infrastructure on GDP growth is important $p=0.00<0.05$ with a positive coefficient. This is confirmed by the simple correlation $R(97.9 \%)$ and determination coefficient $R^{2}$ (95.9) are very high. This means that the services sector is especially dominant in Kosovo and its contribution to growth is much higher than that of other sectors gathered all together. As a general conclusion we say, the findings suggest that the GDP growth is not directly related to FDI inflows. This means that a statistically significance of FDI would mean a better performance of the Kosovo economy which in our FDI case has shown no statistical significance. While, external debt represents a statistical significance but with a negative coefficient, infrastructure has a positive impact in terms of economic performance growth (GDP growth). Statistics show that there is an increase in the economy of Kosovo and this is attributed to the infrastructure, represented by variable telephone lines (mobile). Selecting the determining factors has a great importance in the results of GDP growth, and even statistically FDI are low, which have already entered more in the form of mergers and acquisitions than Greenfield. Policy recommendations based on the findings, propose to encourage and improve the FDI flow in Kosovo. The government should provide a legal framework and suitable policy for external businesses in Kosovo, a prerequisite for attracting FDI. It is also necessary that Kosovo government formulate appropriate policies for local businesses in order to meet the lack of flows from abroad. Given the causal relation between FDI, GDP and external debt, favorable policies of external debt must be reformulated. Each foreign company that decides to enter any country previously, certain resources of the host country and resources of the host firms how competitive they are, and risk arising if they invest in that country. Therefore it is important for Kosovo that government reformers make the right choice of internal reforms and incentives, creation of prerequisites for foreign investors to enter without hesitation in Kosovo. Despite the contribution increase of the primary sector of services to GDP growth in Kosovo, the economic and fiscal policies must be changed in favor of increasing the contribution of other primary and secondary sectors, effects on long-term growth of the services sector has no strong basic expectations.

\section{References}

[1] Borensztein E., J. De Gregorio and Lee J W (1997). How does foreign direct investment affect economic growth? Journal of International Economics 45 (1998), pp 115-135.

[2] De Mello LR (1997). Foreign Direct Investment in Developing Countries and Growth: A Survey selection. Journal of Development Studies 34 (1), pp 1-34.

[3] Mustafa Seref Aki and Valerica Vlad. (2011). The Relationship between Education and Foreign Direct Investment: Testing the Inverse U Shape.pg.32.. The Relationship between Education and Foreign Direct Investment: Testing the Inverse U Shape.pg.32.

[4] Gould.Gould., Melecky. M. (2016). Risks and Returns: Managing Financial Trade-Offs for Inclusive Growth in Europe and Central Asia.pp.1-295. World Bank Group. https://openknowledge.worldbank.org/bitstream/handle/10986/25494/9781464809675.pdf? sequence=7\&isAllowed

[5] Gujarati D.N. (2004): Basic Econometrics., 3e, 1995.pp 10, Fourth Edition. () The McGraw-Hill Companies.

[6] Buletini Mujor Statistikor 2017 / N.18 6.pp.1-151. http://bak-kos.org/repository/docs/2015/BQK BMS 186 al.pdf

[7] Sistemi Financiare informata mujore. 02. Janar 2017.pdf (Financial System monthly information) http://www.bqkkos.org/repository/docs/2015/02.\%20FINALI_SISTEMI\%20FINANCIAR_Janar\%202017

[8] Raporti I Stabilitetit Financiare. Nr.10. dhjetor 2016. Pp.1-114. http://bgkkos.org/repository/docs/2015/02.\%20BQK RSF\%20-\%2010.pdf(Report of Financial Stability. No.10. December 2016).

[9] Word Bank Group (2017). International Deept Statistics.pp.1-99. https://openknowledge.worldbank.org/bitstream/handle/10986/25697/9781464809941.pdf 